\title{
Candidate Genes Colocalized to Linkage Regions in Inflammatory Bowel Disease
}

\author{
K. Martina M. Radlmayr ${ }^{a} \quad$ R. Borchers ${ }^{a} \quad$ M. Heinzlmanna ${ }^{a}$ C. Folwaczny ${ }^{b}$ \\ a Medizinische Klinik und b Medizinische Poliklinik und Chirurgische Klinik der Universität, Standort Innenstadt, \\ Ludwig-Maximilians Universität München, Deutschland
}

\section{Key Words}

Inflammatory bowel disease $\cdot$ Candidate gene $\cdot$ Vitamin $D$ receptor $\cdot$ Tumor necrosis factor- $\alpha \cdot$ Epidermal growth factor receptor . Crohn's disease. Ulcerative colitis

\begin{abstract}
Background and Aims: The genes encoding for tumor necrosis factor- $\alpha$ (TNF- $\alpha$ ), epidermal growth factor receptor (EGFR) and the vitamin D receptor (VDR) are colocalized to inflammatory bowel disease-associated linkage regions on chromosomes 6,7 and 12. An association study of these gene polymorphisms with ulcerative colitis or Crohn's disease and a stratification according to disease phenotypes was performed in order to identify gentically homogenous subgroups. Patients and Methods: 119 healthy, unrelated controls, 95 patients with Crohn's disease and 93 patients with ulcerative colitis were genotyped for the ( $G$ to A) -308 TNF- $\alpha$ promoter polymorphism on chromosome 6 , the codon 497 EGFR polymorphism on chromosome 7 and the Taql polymorphism of the VDR gene on chromosome 12. After genotyping, patients were stratified according to the respective disease phenotype. Results: A disequilibrium in the distribution of the VDR genotypes was found in patients with ulcerative colitis compared to controls $(p=0.024)$. In fistulizing and fibrostenotic Crohn's disease the ' $T$ ' genotype was significantly reduced compared with other phenotypes $(p=0.006)$, whereas the ' $t$ ' genotype was found more frequently $(p=0.04)$. The frequency of the
\end{abstract}

WT allele of the EGFR gene was significantly higher in ulcerative colitis $(p=0.04)$ than in controls. Further significant differences, concerning the associations of the different polymorphisms and disease susceptibility or clinical phenotypes, were not observed. Conclusions: Regardless of the disease phenotype, the associations between the polymorphisms and inflammatory bowel disease investigated herein are modest, even after stratification for the disease phenotypes. Hence, these polymorphisms are unlikely to confer the reported linkage between inflammatory bowel disease and chromosomes 6,7 and 12 .

Copyright $\odot$ 2002S. Karger AG, Basel

\section{Introduction}

One of the most attractive hypotheses concerning the etiology of inflammatory bowel disease comprises an aberrant regulation of the mucosal immune response which probably results in a loss of the immune tolerance against luminal antigens. Thus, genes involved in the regulation of the immune response and intestinal mucosal repair and defense are apparently candidates for genetic studies. Genome wide linkage analyses in large patient cohorts of different ethnic backgrounds have defined inflammatory bowel disease susceptibility loci located on chromosomes 3, 6, 7, 12 and 16 employing microsatellite markers in affected relative pairs [1-13], although linkage could not be confirmed by every group $[7,14,15]$.

\begin{tabular}{ll}
\hline KARGER & ( ) 2002 S. Karger AG, Basel \\
Fax +4161306 1234 & 0012-2823/02/0662-0121\$18.50/0 \\
$\begin{array}{l}\text { E-Mail karger@karger.ch } \\
\text { www.karger.com }\end{array}$ & $\begin{array}{l}\text { Accessible online at: } \\
\text { www.karger.com/dig }\end{array}$
\end{tabular}

PD Dr. C. Folwaczny

Medizinische Poliklinik und Chirurgische Klinik, Klinikum Innenstadt

Ludwig-Maximilians Universität, Nussbaumstrasse 20

D-80336 München (Germany), Tel. +49 8951602625

Fax +49895160 4187, E-Mail Christian.Folwaczny@medinn.med.uni-muenchen.de 
The tumor necrosis factor- $\alpha(\mathrm{TNF}-\alpha)$ gene is located on chromosome 6 within the HLA class III region, telomeric to the class II and centromeric to the class I region. Linkage of inflammatory disease has been demonstrated recently to this region which is situated on the short arm of chromosome 6 [4]. The biallelic $\mathrm{G}$ to A transition polymorphism located at position -308 in the TNF promoter region defines the TNF1 $(-308 \mathrm{G})$ and the TNF2 $(-308 \mathrm{~A})$ alleles [16]. Elevated circulating levels of TNF- $\alpha$ were described in individuals homozygous for TNF2 [17].

Epidermal growth factor receptor (EGFR) is a 170$\mathrm{kDa}$ transmembrane glycoprotein which mediates the effects of epidermal growth factor (EGF) and transforming growth factor $-\alpha$ (TGF- $\alpha)$. EGF enhances host natural defenses against mucosal injury by creating a dilutional barrier that restricts injury from caustic agents [18]. In animal models of colitis a marked increase in EGFR immunoreactivity has been noted [19], suggesting a role for EGF in intestinal mucosal repair and defense. Moriai et al. [20] identified a $\mathrm{G}$ to A transition at codon 497 of the EGFR resulting in an arginine to lysine substitution. The human EGFR maps to chromosome 7p12, a region which has been linked to inflammatory bowel disease [1].

The gene encoding for the vitamin $\mathrm{D}$ receptor (VDR) is situated within $3 \mathrm{cM}$ to the microsatellite marker D12S85 on chromosome 12, which has been linked to ulcerative colitis and Crohn's disease by different groups [1, 3, 5, 21]. Vitamin $D_{3}$ affects calcium hemostasis and exhibits distinct immunomodulatory effects, by activating macrophages and monocytes and suppressing lymphocyte proliferation and immunoglobulin production $[22,23]$. The proinflammatory transcription factor NFKB is inhibited by vitamin $\mathrm{D}_{3}$ and subsequently the expression of proinflammatory cytokines is impaired [24].

The present study sought to address whether immunorelevant genes colocalized to previously described linkage regions are associated with inflammatory bowel disease. In addition, a stratification of the respective polymorphisms according to the disease phenotypes was performed in order to identify genetically homogenous subgroups.

\section{Methods}

\section{Study Population}

Blood samples were obtained from 95 patients with Crohn's disease (male:female ratio 33:62; age $40 \pm 14$ years), 93 patients with ulcerative colitis (male:female ratio 41:52; age $43 \pm 14$ years), and 119 healthy, unrelated controls. The diagnosis of Crohn's disease and ulcerative colitis and the respective disease phenotype, e.g. fistuliz- ing, fibrostenotic, were assessed by conventional clinical, endoscopic, histopathological and radiologic criteria. Patients were recruited consecutively between 1986 and 2000 (urban, middle European population).

\section{DNA Extraction}

Genomic DNA was prepared from buffy coat layers employing a commercially available kit (QIAamp DNA Blood Mini Kit; Quiagen, Hilden, Germany).

\section{Determination of the TNF- $\alpha$ Genotype}

Two allelic forms were genotyped, referred to as TNF1 and $\mathrm{TNF}$, that are identical apart from a single base transition ( $\mathrm{G}$ to $\mathrm{A}$ ) at -308 of the TNF- $\alpha$ promoter. Typing was performed by PCR amplification using the primers as previously described [25]. The primer pair C1 5'-TCTCGGTTTCTTCTCCATCG-3' was used in combination with either the primer C2 5'-TAGGTTTTGAGGGGCATGG-3' for amplifying TNF1 or the $5^{\prime}$ primer C3 5'-ATAGGTTTTGAGGGGCATGA-3' for amplifying the 184-bp TNF2 fragment. The primer pair GAPDHse/GAPDHas producing a 310-bp fragment out of the GAPDH gene was added to each reaction as an internal control. The 184-bp fragment of the TNF- $\alpha$ promoter region was amplified by a 32-cycle PCR with a hot start Taq polymerase (HotStarTaq DNA Polymerase, Qiagen $\mathrm{GmbH}$ ) employing a Biometra-Thermocycler (Biometra, Göttingen, Germany). PCR was carried out under standard conditions. Annealing was performed for $60 \mathrm{~s}$ at $60^{\circ} \mathrm{C}$. PCR products were analyzed using a $2 \%$ agarose gel (Sigma-Aldrich Chemie GmbH, Steinheim, Germany).

\section{EGFR (or HER) Polymorphism}

Primer sequences 5'-GTTTGGGACCTCCGGTCAG-3' and 5'CTTGTCCACGCATTCCC TGC- ${ }^{\prime}$ 'spanning the BstNI restriction site were identical to those described by Moriai et al. [20]. For PCR amplification (Cycler and $T a q$ as above), standard conditions were used (annealing temperature $59^{\circ} \mathrm{C}$ for $1 \mathrm{~min}, 35$ cycles). $20 \mu \mathrm{l}$ of the 102-bp PCR product was digested with BstNI (New England Biolabs) at $65^{\circ} \mathrm{C}$ for $2 \mathrm{~h}$. Alleles were separated on $4 \%$ NuSieve ethidium bromide-stained gels. In the case of a homozygous wild-type individual, one undigested 102-bp band was obtained. The $\mathrm{G}$ to A transition at codon 497 created a BstNI restriction site so that three bands (102, 54 and $48 \mathrm{bp}$ ) were present in heterozygous individuals. If a patient had a homozygous transition, only the 54- and the 48-bp band were seen.

\section{Analysis of the Vitamin-D Receptor Genotype}

Sequence-specific primers were used for typing the biallelic VDR polymorphism as described elsewhere [26]. The consensus primer 5'CAGAGCATGGACAGGGAGC-3' was either used with primer T 5'-CGGTCCTGGATGGCCTCA-3' giving rise to the T allele or the primer $t$ 5'-CGGTCCTGGATGgCCTCG-3' for amplifying the 310$\mathrm{bp} t$ fragment. As an internal control the primer pair $\mathrm{F} / \mathrm{R}$ was added to each reaction producing a 700-bp fragment out of the GAPDH gene. At an annealing temperature of $66^{\circ} \mathrm{C}$ for $50 \mathrm{~s}$, PCR was performed under standard conditions. PCR products were also visualized in $2 \%$ agarose gel.

\section{Statistical Analysis}

Statistical evaluation was performed by use of the Fisher's exact test.

$\overline{\text { Digestion 2002;66:121-126 }}$

Martin/Radlmayr/Borchers/Heinzlmann/ Folwaczny 


\section{Results}

The genotype frequencies of the three polymorphisms investigated herein are depicted in table 1. The frequencies of the VDR genotypes in ulcerative colitis were found in significant disequilibrium $(\mathrm{p}=0.024)$ : The ' $\mathrm{Tt}$ ' genotype was found less frequent (41 vs. 58\%), whereas the ' $t \mathrm{t}$ ' genotype was more prevalent when compared to controls (29 vs. 16\%). The frequency of the WT allele in the EGFR

Table 1. Genotype frequencies in the different groups of the study population

\begin{tabular}{llll}
\hline & Controls & $\begin{array}{l}\text { Crohn's disease } \\
95 \text { patients }\end{array}$ & $\begin{array}{l}\text { Ulcerative colitis } \\
93 \text { patients }\end{array}$ \\
\hline TNF- $\alpha$ & & & \\
TNF1/TNF1 & $87(73 \%)$ & $78(82 \%)$ n.s. & $74(80 \%)$ n.s. \\
TNF1/TNF2 & $32(27 \%)$ & $17(18 \%)$ & $19(20 \%)$ \\
\hline EGFR & & & \\
WT/WT & $62(52 \%)$ & $50(53 \%)$ n.s. & $60(65 \%)$ n.s. \\
WT/EGFR2 & $47(39 \%)$ & $37(39 \%)$ n.s. & $30(32 \%)$ n.s. \\
EGFR2/EGFR2 & $10(9 \%)$ & $8(8 \%)$ n.s. & $3(3 \%)$ n.s. \\
\hline VDR & & & \\
T/T & $31(26 \%)$ & $37(39 \%)$ n.s. & $28(30 \%) \mathrm{p}=0.024$ \\
T/t & $69(58 \%)$ & $45(47 \%)$ & $38(41 \%)$ \\
t/t & $19(16 \%)$ & $13(14 \%)$ & $27(29 \%)$ \\
\hline
\end{tabular}

$\mathrm{TNF} 1=$ Wild-type allele, $\mathrm{TNF} 2=\mathrm{G}$ to $\mathrm{A}$ transition, $\mathrm{WT}=$ wildtype, $\mathrm{T}=$ wild-type allele, $\mathrm{t}=\mathrm{A}$ to $\mathrm{C}$ substitution, n.s. $=$ not significant. gene was increased in ulcerative colitis $(p=0.04)$. Further significant differences concerning the frequency of the TNF- $\alpha$ and the EGFR polymorphism between patients and controls were not observed (see table 2).

The frequencies of the different polymorphisms which were observed after stratification according to the disease phenotype in Crohn's disease are listed in table 3. The 'TT' genotype shared a negative and the 'tt' a positive association with the fistulizing and fibrostenotic phenotype ( $p=0.006$ and 0.04 , respectively). Further significant differences in the genotype distribution were not observed after stratification with regard to clinical phenotypes.

\section{Discussion}

Inflammatory bowel diseases are heterogeneous with respect to clinical behavior, response to medical treatment and prognosis. The concept of genetic heterogeneity in inflammatory bowel disease is supplied by several observations [27, 28]. In accordance with this concept an appropriate understanding of the etiology of inflammatory bowel disease will only be possible after stratification of patients according to clinical or genetic markers in order to identify genetically homogenous subgroups.

TNF- $\alpha$ is a proinflammatory cytokine of paramount importance in inflammatory bowel disease. Increased concentrations of TNF- $\alpha$ were described in serum [29], stool [30] and the intestinal mucosa of patients with Crohn's disease [31, 32]. The administration of antiTNF- $\alpha$ antibodies has profound effects in active Crohn's disease [33-35]. The individual variations in TNF- $\alpha$ pro-
Table 2. Allele frequency in the different groups of the study population

\begin{tabular}{lrrl}
\hline & Controls & $\begin{array}{l}\text { Crohn's disease } \\
95 \text { patients/190 alleles }\end{array}$ & $\begin{array}{l}\text { Ulcerative colitis } \\
93 \text { patients/186 alleles }\end{array}$ \\
\hline TNF- $\alpha$ & & & \\
TNF1 allele & $206 / 238(87 \%)$ & $173 / 190(91 \%)$ n.s. & $\begin{array}{c}167 / 186(90 \%) \text { n.s. } \\
19 / 186(10 \%)\end{array}$ \\
TNF2 allele & $32 / 238(13 \%)$ & $17 / 190(9 \%)$ & \\
\hline$E G F R$ & & & $150 / 186(81 \%) \mathrm{p}=0.04$ \\
WT allele & $171 / 238(72 \%)$ & $137 / 190(72 \%)$ n.s. & $36 / 186(19 \%)$ \\
EGFR2 allele & $67 / 238(28 \%)$ & $53 / 190(28 \%)$ & \\
\hline$V D R$ & & & $94 / 186(51 \%)$ n.s. \\
T allele & $131 / 238(55 \%)$ & $119 / 190(63 \%)$ n.s. & $92 / 186(49 \%)$ \\
t allele & $107 / 238(45 \%)$ & $71 / 190(37 \%)$ & \\
\hline
\end{tabular}

TNF1 $=$ Wild-type allele, $\mathrm{TNF} 2=\mathrm{G}$ to A transition, $\mathrm{WT}=$ wild-type, $\mathrm{EGFR} 2=\mathrm{G}$ to $\mathrm{A}$ transition, $\mathrm{T}=$ wild-type allele, $\mathrm{t}=\mathrm{A}$ to $\mathrm{C}$ substitution, $\mathrm{n} . \mathrm{s}$. = not significant. 
Table 3. Genotype frequencies according to the disease phenotype in Crohn's disease

\begin{tabular}{|c|c|c|c|c|}
\hline & $\begin{array}{l}\text { Fistulizing } \\
15 \text { patients }\end{array}$ & $\begin{array}{l}\text { Stenotic } \\
24 \text { patients }\end{array}$ & $\begin{array}{l}\text { Fistulizing }+ \text { stenotic } \\
40 \text { patients }\end{array}$ & $\begin{array}{l}\text { Nonfistulizing, nonstenotic } \\
16 \text { patients }\end{array}$ \\
\hline \multicolumn{5}{|l|}{$T N F-\alpha$} \\
\hline TNF1/TNF1 & $11(73 \%)$ n.s. & $20(83 \%)$ n.s. & $35(88 \%)$ n.s. & $12(75 \%)$ n.s. \\
\hline TNF1/TNF2 & $4(27 \%)$ & $4(17 \%)$ & $5(13 \%)$ & $4(25 \%)$ \\
\hline \multicolumn{5}{|l|}{$E G F R$} \\
\hline WT/WT & $10(67 \%)$ n.s. & $14(58 \%)$ n.s. & $19(48 \%)$ n.s. & 7 (44\%) n.s. \\
\hline WT/EGFR2 & $4(27 \%)$ n.s. & $8(33 \%)$ n.s. & $16(40 \%)$ n.s. & $9(56 \%)$ n.s. \\
\hline EGFR2/EGFR2 & 1 (7\%)n.s. & $2(8 \%)$ n.s. & $5(13 \%)$ n.s. & 0 n.s. \\
\hline \multicolumn{5}{|l|}{$V D R$} \\
\hline $\mathrm{T} / \mathrm{T}$ & $7(47 \%)$ n.s. & $13(54 \%)$ n.s. & $9(23 \%) p=0.006$ & $8(50 \%)$ n.s. \\
\hline $\mathrm{T} / \mathrm{t}$ & $7(47 \%)$ n.s. & $9(38 \%)$ n.s. & $22(55 \%)$ n.s. & 7 (44\%) n.s. \\
\hline$t / t$ & $1(7 \%)$ n.s. & $2(8 \%)$ n.s. & $9(23 \%) p=0.040$ & $1(6 \%)$ n.s. \\
\hline
\end{tabular}

$\mathrm{TNF} 1=$ Wild-type allele, $\mathrm{TNF} 2=\mathrm{G}$ to A transition, $\mathrm{WT}=$ wild-type, EGFR2 $=\mathrm{G}$ to $\mathrm{A}$ transition, $\mathrm{T}=$ wild-type allele, $\mathrm{t}=\mathrm{A}$ to $\mathrm{C}$ substitution, n.s. = not significant. $\mathrm{p}$ values vs. controls.

duction are likely to be caused by regulatory polymorphisms in or near the TNF- $\alpha$ gene, such as the polymorphism at position -308 in the TNF promoter region. Several groups have shown that the TNF2 allele polymorphism is associated with increased transcription factor binding as well as increased transcriptional activity compared to the TNF1 allele [36-38]. This correlates with increased circulating concentrations of TNF- $\alpha$ in individuals homozygous for TNF2, as compared to individuals homozygous for TNF1, whereas heterozygous individuals display intermediate levels of TNF- $\alpha$ [17]. However, in contrast to previously reported data [39, 40], we were unable to detect an association between the -308 TNF- $\alpha$ polymorphism and ulcerative colitis or Crohn's disease. Such an association was also not observed after stratification according to the clinical phenotype in Crohn's disease.

Exogenous administration of EGF significantly reduces the mucosal damage and inflammation induced in animal models of colitis [41]. Although the mechanism by which EGF provides protection is currently unknown, it has been postulated that through its ability to stimulate mucin glycoprotein synthesis and secretion [42-44], EGF enhances host natural defenses against mucosal injury by creating a dilutional barrier, that restricts injury from caustic agents [18]. EGFR might therefore play an important role in intestinal mucosal repair and defense. In 1993, a variant EGFR was identified that had an arginine to lysine substitution at codon 497 [20]. Wild-type EGFR differs in contrast to mutant EGFR with respect to epithelial proliferation following the administration of EGF and TGF- $\alpha$ in rodents [45]. Thus, it is appears possible that mutations which influence the function or expression of EGFR might predispose to inflammatory bowel disease. A slight but significant association between the WT allele and ulcerative colitis was found. Further associations regarding the genotype or disease phenotype were not observed.

The immunoregulating effects of the cellular receptor for $1,25(\mathrm{OH})_{2}$ vitamin $\mathrm{D}_{3}$ are complex and not yet finally understood. The TaqI polymorphism, located at the $3^{\prime}$ end of the VDR gene, has been associated with bone mineral density and osteoporosis in a number of different populations [46], as well as with the risk of prostate cancer [47]. The ' $\mathrm{tt}$ ' genotype of the TaqI polymorphism seems to predispose to a variety of infectious diseases, such as tuberculosis, chronic hepatitis B and leprosy [48-50]. Since the TaqI polymorphism does not result in an amino acid coding change (it is an A to $\mathrm{C}$ base substitution at codon 352 of exon 8 , both isoleucine), the mechanism of how the polymorphism might affect disease susceptibility remains unclear. In addition, the data reflecting the functional significance of the TaqI polymorphism are contradictory [51]. Under the assumption that the ' $t$ ' genotype is associated with enhanced VDR transcription, a stronger cell-mediated immune response with increased mac- 
rophage or monocyte activation could predispose to inflammatory bowel disease. Furthermore, an impaired mucosal antibody secretion resulting in increased susceptibility to bacterial infection which could trigger inflammatory bowel disease. In contrast to previously reported data [26], we were unable to detect a positive association between the ' $\mathrm{tt}$ ' genotype and Crohn's disease, instead we found a disequilibrium in the distribution of the VDR genotypes in ulcerative colitis. Compared to the controls, the ' $\mathrm{Tt}$ ' genotype was less frequent in patients with ulcerative colitis, whereas the 'tt' genotype was found more often. After stratification of patients with Crohn's disease regarding the clinical phenotype, we found a negative association of the 'TT' genotype, as well as a positive association of the ' $\mathrm{tt}$ ' genotype with the fistulizing and fibrostenotic phenotype. However, concerning the conflicting nature of the data and the weakness of the associations, it appears unlikely that the TaqI polymorphism of the VDR gene is an important determinant of disease susceptibility.
In summary, with the exception of the associations between the VDR genotypes and inflammatory bowel disease and the weak association of the WT allele and the EGFR gene, further significant associations between the immunologically relevant gene polymorphisms which are colocalized to previously reported linkage regions in inflammatory bowel disease were not observed in the present study. Thus, it appears unlikely that linkage of chromosomes 6,7 and 12 with inflammatory bowel disease is due to polymorphisms of the genes investigated herein.

\section{Acknowledgments}

This paper contains parts of the doctoral thesis of $\mathrm{K}$. Martin and M. Radlmayr. The authors thank Dr. J. Klose for helpful advice in performing the statistical analysis. The project was supported by the grant of 'Förderung von Forschung und Lehre (FoFöLa Reg-Nr. 69)' and the Friedrich-Baur-Institut, Munich, Germany, to Ch. Folwaczny.

\section{References}

1 Satsangi J, Parkes M, Louis E, Hahimoto L, Kato N, Welsh K, Terwilliger JD, Lathrop GM, Bell JI, Jewell DP: Two stage genome-wide search in inflammatory bowel disease provides evidence for susceptibility loci on chromosomes 3, 7 and 12. Nat Genet 1996;14:199202 .

2 Hampe J, Lynch NJ, Daniels S, Bridger S, Macpherson AJS, Stokkers P, Forbes A, LennardJones JE, Mathew CG, Curran ME, Schreiber $\mathrm{S}$ : Fine mapping of the chromosome $3 \mathrm{p}$ susceptibility locus in inflammatory bowel disease. Gut 2001;48:191-197.

3 Curran ME, Lau KF, Hampe J, Schreiber S, Bridger S, Macpherson AJ, Cardon LR, Sakul H, Harris TJ, Stokkers P, Van Deventer SJ, Mirza M, Raedler A, Kruis W, Meckler U, Theuer D, Herrmann T, Gionchetti P, Lee J, Mathew C, Lennard-Jones J: Genetic analysis of inflammatory bowel disease in a large European cohort supports linkage to chromosomes 12 and 16. Gastroenterology 1998;115:10661071.

4 Hampe J, Shaw SH, Saiz R, Leysens N, Lantermann A, Mascheretti S, Lynch NJ, Macpherson AJ, Bridger S, van Deventer S, Stokkers P, Morin P, Mirza MM, Forbes A, Lennard-Jones JE, Mathew CG, Curran ME, Schreiber S: Linkage of inflammatory bowel disease to human chromosome 6p. Am J Hum Genet 1999 65:1647-1655.
5 Hampe J, Schreiber S, Shaw S, Lau KF, Bridger S, Macpherson AJ, Cardon LR, Sakul H, Harris TJ, Buckler A, Hall J, Stokkers P, van Ceventer SJ, Nurnberg P, Mirza MM, Lee JC, Lennard-Jones JE, Mathew CG, Curran ME: A genomewide analysis provides evidence for novel linkages in inflammatory bowel disease in a large European cohort. Am J Hum Genet 1999;64:808-816.

6 Hugot JP, Laurentpuig P, Gower-Rousseau C, Olson JM, Lee JC, Beaugerie L, Naom I, Dupas JL, Vangossum A, Orholm M, Bonaitipellie C, Weissenbach J, Mathew CG, Lennardjones JE, Cortot A, Colombel JF, Thomas G: Mapping of a susceptibility locus for Crohn's disease on chromosome 16. Nature 1996;379:821-823.

7 Brant SR, Fu Y, Fields CT, Baltazar R, Ravenhill G, Pickles MR, Rohal PM, Mann J, Kirschner BS, Jabs EW, Bayless TM, Hanauer SB, Cho JH: American families with Crohn's disease have strong evidence for linkage to chromosome 16 but not chromosome 12 . Gastroenterology 1998;115:1056-1061.

8 Cho JH, Nicolae DL, Gold LH, Fields CT, LaBuda MC, Rohal PM, Pickles MR, Yin L, FuY, Mann JS, Kirschner VS, Jabs EW, Weber J, Hanauer SB, Bayless TM, Brant SR: Identification of novel susceptibility loci for inflammatory bowel diseases on chromosomes $1 p, 3 q$ and 4q: Evidence for epistasis between $1 \mathrm{p}$ and IBD1. Proc Natl Acad Sci USA 1998;95:75027507.
9 Cavanaugh JA, Callen DF, Wilson SR, Stanford PM, Sraml ME, Gorska M, Crawford J, Whitmore SA, Shlegel C Foote S, KohonenCorish M, Pavli P: Analysis of Australian Crohn's disease pedigrees refines the localization for susceptibility to inflammatory bowel disease on chromosomes 16. Ann Hum Genet 1998;62:291-298.

10 Parkes M, Varmada MM, Satsangi J, Weeks DE, Jewell DP, Duerr RH: The IBD2 locus shows linkage heterogeneity between ulcerative colitis and Crohn disease. Am J Hum Genet 2000;67:1605-1610.

11 Riox JD, Silverberg MS, Daly MJ, Steinhart AH, McLeod RS, Griffiths AM, Green T, Brettin TS, Stone V, Bull SB, Bitton A, Williams CN, Greenberg GT, Cohen Z, Lander ES, Hudson TJ, Siminovitch KA: Genomewide search in Canadian families with inflammatory bowel disease reveals two novel susceptibility loci. Am J Hum Genet 2000;66:1863-1870.

12 Cavanaugh J: International collaboration provides convincing linkage replication in complex disease through analysis of a large pooled data set: Crohn disease and chromosome 16 . Am J Hum Gent 2001;68:1165-1 171.

13 Paavola P, Helio T, Kiuru M, Halme L, Turunen U, Terwilliger J, Karvonen AL, Julkunen R, Niemela S, Nurmi H, Farkkila M, Kontula $\mathrm{K}$ : Genetic analysis in Finnish families with inflammatory bowel disease supports linkage to chromosome 3p21. Eur J Hum Genet 2001; 9:328-334. 
14 Rioux JD, Daly MJ, Green T, Stone V, Lander ES, Hudson TJ, Steinhart AH, Bull S, Cohen Z, Greenberg G, Griffiths A, McLeod R, Silverberg M, Williams $\mathrm{CN}$, Siminovitch KA: Absence of linkage between inflammatory bowel disease and selected loci on chromosomes 3, 7 , 12 and 16. Gastroenterology 1998;115:10621065 .

15 Vermeire S, Peeters M, Vlietinck R, Parkes M, Satsangi J, Jewell D, Rutgeerts P: Exclusion of linkage of Crohn's disease to previously reported regions on chromosomes 12,7 and 3 in the Belgian population indicates genetic heterogeneity. Inflamm Bowel Dis 2000;6:165170.

16 Wilson AG, di Giovine FS, Blakemore AIF, Duff GW: Single base change in the human tumor necrosis factor- $\alpha$ gene detectable by NcoI restriction of a PCR product. Hum Mol Genet 1992;1:353.

17 Bouma G, Crusius JBA, Oudkerk Pool M, Kolkman JJ, von Blomberg BM, Kostnese PJ, Giphart MJ, Schreuder GM, Meuwissen SG, Pena AS: Secretion of tumor necrosis factor- $\alpha$ and lymphotoxin- $\alpha$ in relation to polymorphisms in the TNF genes and HLA-DR alleles. Relevance for inflammatory bowel disease. Scand J Immunol 1996;43:456-463.

18 Grisham MB, Von Ritter C, Smith BF, LaMont TJ, Granger DN: Interaction between oxygen radicals and gastric mucin. Am J Physiol 1987;253:G93-G96.

19 Reinshagen M, Procaccino F, McRoberts JA, Lakshmanan J, Eysselein VE et al: Up-regulation of EGF-binding sites in rat colitis (abstract). Gastroenterology 1993;104:A642.

20 Moriai T, Kobrin MS, Korc M: Cloning of a variant epidermal growth factor receptor. Biochem Biophys Res Commun 1993;191:10341039.

21 Duerr RH, Barmada MM, Zhang L, Davis S, Preston RA, Chensny LJ, Brown JL, Ehrlich GD, Weeks DE, Aston CE: Linkage and association between inflammatory bowel disease an a locus on chromosome 12. Am J Hum Genet 1998;63:95-100.

22 Rook GA, Steele J, Fraher L, Barker S, Karmali R, O'Riordan J, Stanford J: Vitamin $\mathrm{D}_{3}, \gamma-$ interferon and control of proliferation of $\mathrm{MycO}$ bacterium tuberculosis by human monocytes. Immunology 1986;57:159-163.

23 Lemire JM, Archer DC, Beck L, Spiegelberg HL: Immunosuppressive actions of 1,25-dihydroxyvitamin $\mathrm{D}_{3}$ : Preferential inhibition of TH1 functions. J Nutr 1995;125:1704S1708S.

24 Yu XP, Belllido T, Manolagas SC: Down-regulation of NF- $\mathrm{KB}$ protein levels in activated human lymphocytes by 1,25-dihydroxivitamin $D_{3}$. Proc Natl Acad Sci USA 1995;92:10990_ 10994.

25 Verjans GMGM, Brinkman BMN, van Doornik CEM, Kijlstra A, Verweij CL: Polymorphism of tumour necrosis factor- $\alpha$ at position -308 in relation to ankylosing spondylitis. Clin Exp Immunol 1994;97:45-47.
26 Simmons JD, Mullighen C, Welsh KI, Jewell DP: Vitamin D receptor gene polymorphism: Association with Crohn's disease susceptibility. Gut 2000;47:211-214.

27 Vermeire S, Peeters M, Vlietinck R, Parkes M, Satsangi J, Jewell D, Rutgeerts P: Exclusion of linkage of Crohn's disease to previously reported regions on chromosomes 12,7 and 3 in the Belgian population indicates genetic heterogeneity. Inflamm Bowel Dis 2000;6:165170.

28 Lesage S, Zouli H, Cezard JP et al: CARD15/ NOD2 mutational analysis and genotype-phenotype correlation in 612 patients with inflammatory bowel disease. Am J Hum Genet 2002; 70:845-857.

29 Murch SH, Lamkin VA, Savage MO, WalkerSmith JA, MacDonald TT: Serum concentrations of tumour necrosis factor- $\alpha$ in childhood chronic inflammatory bowel disease. Gut 1991;32:913-917.

30 Braegger CP, Nichoos S, Murch SH, Stephens $S$, MacDonald TT: Tumor necrosis factor- $\alpha$ in stool as a marker of intestinal inflammation. Lancet 1992;339:89-91.

31 Breese EJ, Michie CA, Nicholls SW, Murch $\mathrm{SH}$, Williams CB, Domizio P, Walker-Smithe JA, MacDonald TT: Tumor necrosis factor- $\alpha$ producing cells in the intestinal mucosa of children with inflammatory bowel disease. Gastroenterology 1994;106:1455-1466.

32 Reinecker HC, Steffen M, Witthoeft T, Pflueger I, Schreiber S, MacDermott RP, Raedler A: Enhanced secretion of tumour necrosis factor$\alpha$, IL- 6 and IL- $1 \beta$ by isolated lamina propria mononuclear cells from patients with ulcerative colitis and Crohn's disease. Clin Exp Immunol 1993;94:174-181.

33 Targan SR, Hanauer SB, Van Deventer SJ, Mayer L, Present DH, Braakman T, DeWoody KL, Schaible TF, Rutgeerts PJ: A short-term study of chimeric monoclonal antibody cA2 to tumor necrosis factor- $\alpha$ for Crohn's disease. N Engl J Med 1997;337:1029-1035.

34 Stack WA, Mann SD, Roy AJ, Heath P, Sopwith M, Freeman J, Holmes G, Long R, Forbes A, Kamm MA, Hawkey CJ: Randomised controlled trial of CDP571 antibody to tumour necrosis factor- $\alpha$ in Crohn's disease. Lancet 1997;349:521-524.

35 Van Dullemen HM, Deventer SJH, Hommes DW, Bijl HA, Jansen J, Tytgat GNJ, Woody J: Treatment of Crohn's disease with anti-tumor necrosis factor chimeric monoclonal antibody (cA2). Gastroenterology 1995;109:129-135.

36 Wilson AG, Symons JA, McDowell TL, McDevitt HO, Duff GW: Effects of a polymorphism in the human tumor necrosis factor- $\alpha$ promoter on transcriptional activation. Proc Natl Acad Sci USA 1997;94:3195-3199.

37 Braun N, Michel U, Ernst BP, Metzner R, Bitsch A, Rieckmann P: Gene polymorphism at position -308 of the tumor necrosis factor- $\alpha$ in multiple sclerosis and its influence on the regulation of TNF- $\alpha$ production. Neurosci Lett 1996;215:75-78.
38 Kroeger KM, Carville KS, Abraham LJ: The -308 tumor necrosis factor- $\alpha$ promoter polymorphism effects transcription. Mol Immunol 1997;34:391-399.

39 Louis E, Satsangi J, Rousssomoustakaki M, Parkes M, Fanning G, Welsh K, Jewell D: Cytokine gene polymorphisms in inflammatory bowel disease. Gut 1996;39:705-710.

40 Bouma G, Xia B, Crusius JB, Bioque G, Koutroubakis I, Von Blomberg BM, Meuwissen SG, Pena AS: Distribution of four polymorphisms in the tumour necrosis factor genes in patients with inflammatory bowel disease. Clin Exp Immunol 1996;103:391-396.

41 Procaccino F, Reinshagen M, Hoffmann P, Zeeh JM, Lakshmanan J, McRoberts JA, Patel A, French S, Eysselein VE: Protective effect of epidermal growth factor in an experimental model of colitis in rats. Gastroenterology 1994; 107:12-17.

42 Sarosiek J, Bilski J, Murty VL, Slomiany A Slomiany BL: Role of salivary epidermal growth factor in the maintenance of physiochemical characteristics of oral and gastric mucus coat. Biochem Biophys Res Commun 1988; 152:1421-1427.

43 Yoshida S, Kasuga S, Hirao Y, Fuwa T, Nakagawa $\mathrm{S}$ : Effect of biosynthetic human epidermal growth factor on the synthesis and secretion of mucin glycoprotein from primary culture of rabbit fundal mucosa cells. In Vitro Cell Dev Biol 1987;23:460-464.

44 Kell SM, Hunter O: Epidermal growth factor stimulates synthesis and secretion of mucus glycoproteins in human gastric mucosa. Clin Sci 1990:452-427.

45 Moriai T, Kobrin MS, Hope C, Speck L, Korc $\mathrm{M}$ : A variant epidermal growth factor receptor exhibits altered type $\alpha$ transforming growth factor binding and transmembrane signaling. Proc Natl Acad Sci USA 1994;91:10217-10221.

46 Morrison NA, Qi JC, Tokita A, Kelly PJ, Crofts L, Nguyen TV, Sambrook PN, Eisman JA: Prediction of bone density from vitamin D receptor alleles. Nature 1994;367:284-287.

47 Ingles SA, Ross RK, Yu MC, Irvine RA, La Pera G, Haile RW, Coetzee GA: Association of prostate cancer risk with genetic polymorphisms in vitamin $\mathrm{D}$ receptor and androgen receptor. J Natl Cancer Inst 1997;89:166-170.

48 Bellamy R, Ruwende C, Corrah T, McAdam KP, Thursz M, Whittle HC, Hill AV: Tuberculosis and chronic hepatitis $\mathrm{B}$ virus infection in Africans and variation in the vitamin D receptor gene. J Infect Dis 1999; 179:721-724.

49 Roy S, Frodsham A, Saha B, Hazra SK, Mascie-Taylor CG, Hill AV: Association of vitamin $D$ receptor genotype with leprosy type. J Infect Dis 1999; 179:187-191.

50 Hill AV: The immunogenetics of human infectious diseases. Annu Rev Immunol 1998;16: 593-617.

51 Mocharla H, Butch AW, Papas AA, Flick JT, Weinstein RS, De Togni P, Jilka RL, Roberson PK, Parfitt AM, Manolagas SC: Quantification of vitamin $\mathrm{D}$ receptor $\mathrm{mRNA}$ by competitive polymerase chain reaction in PBMC: Lack of correspondence with common allelic variants. J Bone Miner Res 1997; 12:726-723 